\title{
Effect of Time of Planting on Cane Yield and Quality Characters in Sweet Sorghum
}

\author{
Chamarthy Venkata Ratnavathi*, Sivanuri Ravi Kumar, Bathula Swaroop Vijay Kumar, \\ Dasari Gopala Krishna, Jagannath Vishnu Patil \\ Directorate of Sorghum Research (Formerly National Research Centre for Sorghum), Hyderabad, India \\ Email: "ratnavathi@sorghum.res.in, ratnanrcs@yahoo.com
}

Received January 24, 2012; revised February 20, 2012; accepted March 6, 2012

\begin{abstract}
Sweet sorghum unlike grain sorghum has potential to accumulate sugars in stalks similar to sugarcane. Short duration and lower water requirements of sweet sorghum are other advantages over sugarcane. Sorghum is usually grown in kharif and rabi seasons. As an energy crop, industry demands supply of green cane as raw material through out the year. Hence this agronomic study was conducted to determine suitable time of planting of sweet sorghum under the agro climatic conditions prevailing in India, so that continuous supply of raw material is assured for factory operations through out the year, especially during the lean period of sugarcane crushing. Various physical and chemical characters of plant and stem juice were studied by taking up bimonthly plantings at four locations using 12 genotypes of sweet sorghum in the first year and quarterly plantings at four locations using 10 genotypes (8 genotypes common in both years) in the second year. Of the six plantings, planting during August and April were found to be not suitable for good sweet sorghum yields, therefore, in the second year, four plantings were taken up i.e., June, October, December and February at six locations. The various attributes selected for observations include cane yield, percent brix of stem juice, percent juice extractability, percent total soluble sugars and reducing sugars in the stem juice. Highest green cane yield and percent juice extractability was observed in June planting in all genotypes followed by February, and December in both bimonthly and quarterly plantings. Juice extraction percentage was also highest in June plantings followed by October, April and December plantings. June plantings recorded highest percent brix followed by December and February plantings in bimonthly plantings, while in quarterly planting, highest percent brix and total sugars in juice was observed in February planting followed by planting in June.
\end{abstract}

Keywords: Genotypes; Date of Planting; Biomass; Juice Extractability; Brix; Total Soluble Sugars; Reducing Sugars

\section{Introduction}

Sorghum tolerates drought relatively well, and it responds to adequate fertility and soil moisture with faster growth [1]. Many types of sorghum are suitable for grain and forage production [2], as well as alternative uses, such as energy, pulp for paper, food products and sugar or ethanol products [3,4]. According to World Energy Outlook (2008) [5], current energy supplies are unsustainable from environmental, economic, and societal standpoints. In addition, it is projected that world energy demands will continue to expand by $45 \%$ from 2008 to 2030 , with an average rate of increase in $1.6 \%$ year $^{-1}$. In 2007, the inter governmental panel on climate change [6] released its fourth assessment report confirming that climate change is accelerating and if current trends continue, energy-related emissions of carbon dioxide $\left(\mathrm{CO}_{2}\right)$ and other greenhouse gases will rise inexorably, pushing up

*Corresponding author. average global temperature by as much as $6^{\circ} \mathrm{C}$ in the long term. The alarming increase in pollution rates has drawn the attention of several countries towards bio-energy and the potential sources. The blending of $5 \%$ ethanol with petrol, demands the ethanol requirements in India by 400 million litres annually. This will automatically increase the requirement of molasses for ethanol production. Sweet sorghum can be the best supplementary crop to sugarcane which requires minimum inputs and water. Thus to obtain self sufficiency it is essential to diversify the cropping pattern and introduce crops like sweet sorghum. Sweet sorghum like any other grain sorghum produces grain, in addition to the stalks which are rich in sucrose. The stalk yield and grain yield of sweet sorghum are in the range of $40-50 \mathrm{t} / \mathrm{ha}$ and $0.8-2 \mathrm{t} / \mathrm{ha}$ respectively. The sugar content in juice varies from $16 \%-23 \%$ brix. Sweet sorghum juice mostly contains sucrose, glucose, and fructose sugars and such type of high sugar crop can be used to produce fuel alcohol [7]. 
Sweet sorghum has drawn the attention of many countries because of many good characteristics like wide adaptability, drought resistance, water logging tolerance, saline-alkali resistance, high growth rate, rapid sugar accumulation with a high biomass yield and above all because of short duration and simple crop husbandry involved in its production compared to sugarcane [8]. Sweet sorghum can be cultivated in nearly all temperate and tropical climatic areas. The sweet sorghum crop can be grown on a low fertility soil on residual moisture where sugarcane cultivation is difficult. Hence, production of alcohol from sweet sorghum juice may be profitable. It can be produced both from the juice of sweet sorghum as well as from grains [9]. Under subtropics and temperate environments, suitable sowing date received great attention [10-12].

In India sugarcane is available only for six months in a year, and rest of the year the machinery and factory personnel are kept idle, and in order to take up the factory operations throughout the year it is essential to introduce crops like sweet sorghum which can use the existing machinery for juice extraction and produce bio-ethanol [13]. This research work was carried out at widely diverse geographic locations in India to determine the suitable time of planting for maximisation of biomass, adaptability, yield potential, stalk quality and harvest sweet sorghum during lean period of sugarcane so that factory operations can be carried out throughout the year and produce bio-ethanol from sweet sorghum.

\section{Materials and Methods}

\subsection{Genotypes, Treatments and Cultural Practices}

A two year field experiment was conducted at 4 different locations viz., Hyderabad, Akola, Rahuri and Parbhani. These locations were selected as sorghum and sugarcane are being traditionally cultivated and distilleries are also located in these places for the commercial use of sweet sorghum cane for ethanol production. The rain fall in the year ranges from May to October in all the above locations and twelve cultivars of sweet sorghum were grown at bimonthly intervals throughout the year (June, August, October, December, February and April) in the first year and 10 cultivars at quarterly intervals in the second year. The 12 genotypes include AKSSV 5, IS 8007, BJ 248, HES-04, Madhura, Wray, NSS-04, CSV 19SS, SSV-84, IS 20962, Keller and CSH 22 SS. These are genotypes from various locations in India and lines introduced from China (BJ-248 and HES-4) and America (Wray and Keller). In the second year 10 genotypes were studied which include NSS-04, CSH 22 SS, BJ 248, Madhura, Wray, CSV 19 SS, SSV-84, Keller, RSSV 47 and NSS 208. Eight genotypes were common in both the years of experiment.
In the first year the crop was sown 6 times in a year, in $1^{\text {st }}$ week of June, August, October, December, February and April. In the second year, crop was sown 4 times in a year, in the first week of June, October, December and February months. The crop was sown in a randomised block design with a spacing of $60 \mathrm{~cm} \times 15 \mathrm{~cm}$ in three replications with 8 rows in each plot of 4 meter length. The soil was red, medium to light soil and field was irrigated immediately after sowing to ensure good germination and uniform crop stand and subsequent irrigations were given as per requirement. High soil moisture during later part of grain maturity may adversely influence juice brix. Hence care was taken to avoid irrigation $10-15$ days before harvest depending on ambient humidity and temperature. If there is rain during harvest stage, harvest was delayed for few days to eliminate the unfavorable influence of rain on juice brix. This was done by testing the juice brix before harvest. The precipitation and temperatures were measured at each planting time and location.

Fertilization was done at the rate of $80 \mathrm{~N}: 40 \mathrm{P}_{2} \mathrm{O}_{5}: 30$ $\mathrm{K}_{2} \mathrm{O} \mathrm{Kg/ha,} \mathrm{half} \mathrm{of} \mathrm{N}$ and entire $\mathrm{P}_{2} \mathrm{O}_{5}$ and $\mathrm{K}_{2} \mathrm{O}$ as basal and the remaining nitrogen as topdressing at 30 days after germination. Plots were kept weed-free with chemical control and hand cultivation. The various agronomic practices, fertilizer application etc, were followed as recommended for sorghum and timely crop protection measures were taken up.

\subsection{Crop Measurements}

The crop growth period of sweet sorghum was four months, 120 days. In each planting, five plants were chosen randomly from each plot from the middle of 6 rows for data collection during the crop maturity stage, one or two days before 120 days of crop growth. The leaf was stripped and cane weight was recorded. These five plants were crushed on an electrically operated two-roller laboratory model cane crusher to estimate juice extractability and quality. Juice extraction percentage (JEP) was calculated according to the equation: JEP $=$ (Juice weight $\times$ 100/stripped stalks weight).

The juice yield (ton/ed) was calculated according to the following equation:

Juice yield $=($ Stripped yield $\times$ juice extr.\% $) / 100$.

The percent brix was recorded using hand held refractometer (Erma, Japan). The juice yield and juice recovery were recorded and percent juice extractability was derived from the weight of the stem used for crushing. Total sugars (TSS) present in the stem juice were estimated by phenol sulphuric acid method [14] and reducing sugars (RSS) by 3,5-dinitro salicylic acid method [15].

\subsection{Statistical Analysis}

All the observations recorded in three replications from 
different plantings and different locations in both the years. These were statistically analyzed using $M$. Stat C software. The data were analysed by two factors RBD, with genotypes as factor A and seasons as factor B. All the statistical tests were based on the methods reported by Snedecor and Cochran (1968) [16].

\section{Results}

\subsection{Effects on Green Cane Yield}

The effect of planting time on mean green cane yield in bimonthly planting is presented in Figure 1. The data on green cane yield (Kg/plant) in different genotypes during six planting times was presented in Table 1. Significant effect was recorded for green cane yield in different planting dates in both the experiments (bimonthly and quarterly planting). There is no difference for the quality characters in different planting times among locations. The average rainfall $(\mathrm{mm})$ of the year during bimonthly planting was 108.36 (Akola), 135.76 (Rahuri), 143 (Hyderabad) and 177 (Parbhani) and during quarterly planting rainfall $(\mathrm{mm})$ recorded was 60.77 (Rahuri), 105.6 (Akola), 132.35 (Parbhani) and 165.77 (Hyderabad). The variation for maximum and minimum temperatures at different locations was not significantly different. The maximum temperature was recorded in the month of May $\left(41^{\circ} \mathrm{C}\right)$ and Minimum temperature was recorded in the month of December $\left(10^{\circ} \mathrm{C}\right)$. The crop was grown with minimum irrigations ( 1 - 2) in Kharif (June planting) and in October, December and February, the crop was

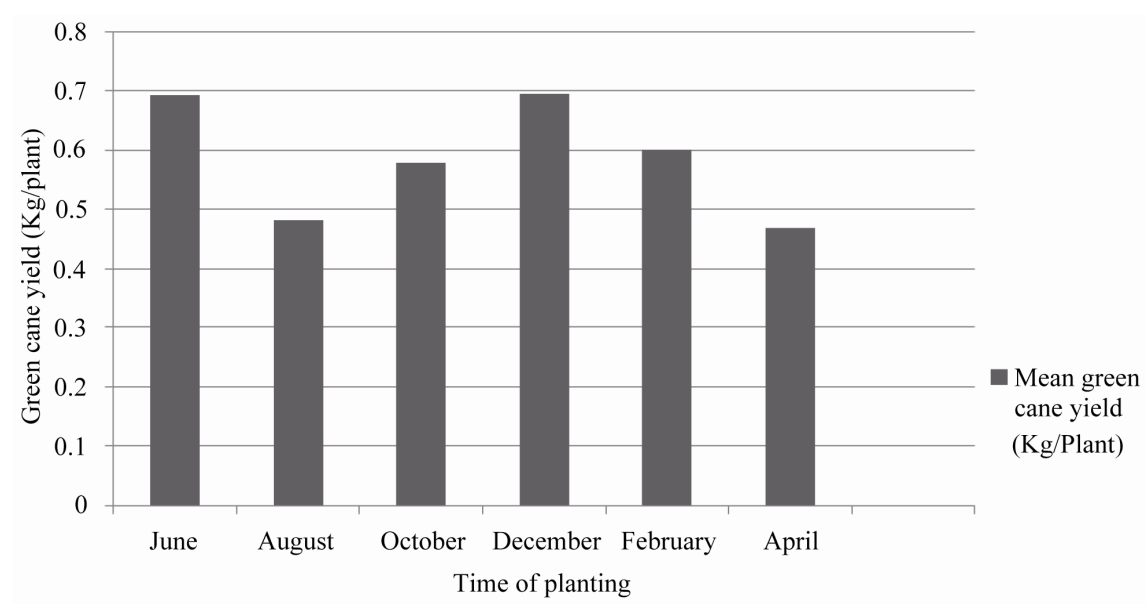

Figure 1. Effect of time of planting (bimonthly) on the green cane yield in Sweet sorghum genotypes.

Table 1. Effect of planting time on green cane yield (Kg/Plant) in bimonthly planting.

\begin{tabular}{|c|c|c|c|c|c|c|c|c|}
\hline \multirow{3}{*}{ S. No. } & \multirow{3}{*}{ Genotype } & \multicolumn{7}{|c|}{ Month of Planting } \\
\hline & & June & August & October & December & February & April & Mean \\
\hline & & \multicolumn{7}{|c|}{ Green Cane Yield (Kg/Plant) } \\
\hline 1 & AKSSV 16 & 0.644 & 0.362 & 0.352 & 0.442 & 0.8 & 0.214 & 0.469 \\
\hline 2 & IS 8007 & 0.575 & $0.445^{`}$ & 0.651 & 0.955 & 0.594 & 0.357 & 0.596 \\
\hline 3 & BJ 248 & 0.499 & 0.477 & 0.558 & 0.843 & 1.16 & 0.633 & 0.695 \\
\hline 4 & HES 04 & 0.56 & 0.524 & 0.492 & 0.517 & 0.492 & 0.386 & 0.495 \\
\hline 5 & MADHURA & 0.75 & 0.439 & 0.534 & 0.677 & 0.339 & 0.229 & 0.495 \\
\hline 6 & WRAY & 0.55 & 0.287 & 1.057 & 0.624 & 0.677 & 0.964 & 0.693 \\
\hline 7 & NSS 04 & 1.03 & 0.556 & 0.63 & 0.516 & 0.5 & 0.327 & 0.593 \\
\hline 8 & CSV 19SS & 0.82 & 0.822 & 0.42 & 0.922 & 0.688 & 0.328 & 0.667 \\
\hline 9 & SSV 84 & 0.948 & 0.478 & 0.521 & 0.523 & 0.482 & 0.453 & 0.5675 \\
\hline 10 & IS 20962 & 0.56 & 0.435 & 0.446 & 0.469 & 0.251 & 0.518 & 0.4465 \\
\hline 11 & Keller & 0.695 & 0.346 & 0.918 & 1.24 & 0.447 & 0.5 & 0.691 \\
\hline \multirow[t]{3}{*}{12} & CSH 22 SS & 0.673 & 0.615 & 0.365 & 0.626 & 0.769 & 0.729 & 0.6295 \\
\hline & Mean & 0.692 & 0.482 & 0.579 & 0.696 & 0.6 & 0.47 & \\
\hline & C. V. & 49.05 & & & & & & \\
\hline
\end{tabular}


grown with irrigations (4 - 6) as and when required. The green cane yield of different genotypes during different seasons was in the range of $0.214 \mathrm{Kg} / \mathrm{plant}$ (AKSSV-16, April plantings) to $1.24 \mathrm{Kg} / \mathrm{plant}$ (Keller, December plantings). Among the different genotypes Keller, Wray, BJ-248 and NSS-04 showed high mean green cane yield (Kg/plant). In most of the genotypes August and April plantings recorded lowest green cane yield (Kg/plant), while February, December, June and October plantings recorded higher green cane yields (Kg/plant).

The effect of planting date on green cane yield in quarterly plantings was presented in Table 2. Highest green cane was observed in June planting in all genotypes followed by February, December and October. CSH 22 SS has yielded highest green cane (0.423 $\mathrm{Kg}$ /plant) followed by RSSV 47 (0.401 Kg/plant). SSV 84 (Check) yielded $0.400 \mathrm{Kg} /$ plant. It was confirmed that June and February plantings yielded higher green cane. For continuous supply even October planting can also be taken up.

\subsection{Grain Yield}

The influence of different date of plantings on grain yield is presented in Table 3. Maximum grain Yield was recorded in the hybrid CSH 22 SS during June plantings (2083 Kg/ha), while minimum grain Yield was recorded in IS-20962 during February plantings (120 Kg/ha). In all the genotypes highest grain yields were recorded during June plantings. Of all the genotypes CSH 22 SS, HES-04, NSS-04 and SSV-84 recorded highest mean grain yield compared to other genotypes. Since the green cane yield, juice extractability and total sugars were important parameters to be considered, grain yield was given less attention.

\subsection{Percent Juice Extractability}

The effect of planting date on percent juice extractability in bimonthly plantings is presented in Table 4. Highest percent juice extractability was recorded in Wray (37.3\%) in June plantings followed by AKSSV-16 (34.91\%) and CSH 22SS (34.7\%) also during June plantings. Percent Juice extractability varied from 22.88 (NSS-04, December Plantings) to $37.30 \%$ (Wray, June plantings). The various genotypes recorded highest percent juice extractability during June plantings except for BJ-248 (October planting), Madhura (December planting), CSV 19SS (February planting) and SSV-84 (October planting).

Table 2. Effect of planting time on green cane yield (Kg/plant) in quarterly planting.

\begin{tabular}{|c|c|c|c|c|c|c|}
\hline \multirow{2}{*}{ S. No. } & \multirow{2}{*}{ Genotype } & \multicolumn{5}{|c|}{ Time of Planting } \\
\hline & & June & October & December & February & Mean \\
\hline 1 & NSS 04 & 0.331 & 0.299 & 0.279 & 0.306 & 0.281 \\
\hline 2 & CSH 22 SS & 0.423 & 0.154 & 0.208 & 0.289 & 0.269 \\
\hline 3 & NSS 208 & 0.269 & 0.124 & 0.263 & 0.326 & 0.245 \\
\hline 4 & Wray & 0.304 & 0.168 & 0.311 & 0.341 & 0.281 \\
\hline 5 & Kellar & 0.302 & 0.237 & 0.306 & 0.368 & 0.303 \\
\hline 6 & BJ 248 & 0.314 & 0.195 & 0.214 & 0.283 & 0.252 \\
\hline 7 & CSV 19SS & 0.372 & 0.226 & 0.245 & 0.262 & 0.276 \\
\hline 8 & RSSV 47 & 0.401 & 0.228 & 0.303 & 0.318 & 0.313 \\
\hline 9 & Madhura & 0.355 & 0.215 & 0.198 & 0.252 & 0.255 \\
\hline 10 & SSV 84 & 0.400 & 0.155 & 0.233 & 0.311 & 0.277 \\
\hline \multicolumn{2}{|c|}{ C. V. (\%) } & \multicolumn{5}{|c|}{2.63} \\
\hline \multicolumn{2}{|r|}{ S. E } & \multicolumn{5}{|c|}{0.58} \\
\hline \multicolumn{2}{|c|}{ CD. (0.05) } & \multicolumn{5}{|c|}{1.19} \\
\hline
\end{tabular}

Table 3. Effect of planting time on grain yield (Kg/ha) in bimonthly planting.

\begin{tabular}{ccccccccc}
\hline \multirow{2}{*}{ S. No. } & Genotype & \multicolumn{7}{c}{ Time of Planting } \\
\cline { 3 - 8 } & & June & August & October & December & February & April & Mean \\
\hline 1 & AKSSV 16 & 694 & 412 & 412 & 136 & 459 & 360 & 412 \\
2 & IS 8007 & 1408 & 1040 & 304 & 239 & 426 & 470 & 648 \\
3 & BJ 248 & 1543 & 830 & 295 & 165 & 462 & 350 & 608 \\
4 & HES 04 & 1793 & 833 & 833 & 586 & 536 & 420 & 834 \\
5 & Madhura & 1640 & 800 & 337 & 207 & 493 & 450 & 655 \\
6 & Wray & 732 & 560 & 422 & 292 & 219 & 310 & 423 \\
7 & NSS 04 & 1736 & 1080 & 329 & 213 & 520 & 610 & 748 \\
8 & CSV 19SS & 732 & 540 & 674 & 412 & 219 & 570 & 525 \\
9 & SSV 84 & 1466 & 1060 & 507 & 369 & 439 & 560 & 734 \\
10 & IS 20962 & 385 & 380 & 323 & 203 & 120 & 210 & 270 \\
11 & Keller & 994 & 500 & 350 & 163 & 209 & 270 & 401 \\
12 & CSH 22SS & 2083 & 950 & 507 & 673 & 1050 & 1050 & 1052 \\
13 & Mean & 1267 & 749 & 741 & 441 & 305 & 429 & 469 \\
\hline
\end{tabular}


Table 4. Effect of planting time on percent juice extractability in bimonthly planting.

\begin{tabular}{ccccccccc}
\hline \multirow{2}{*}{ S. No. } & Genotype & \multicolumn{7}{c}{ Time of Planting } \\
\cline { 3 - 8 } & & June & August & October & December & February & April & Mean \\
\hline 1 & AKSSV 16 & 34.928 & 24.702 & 33.275 & 27.497 & 26.615 & 25.467 & 28.747 \\
2 & IS 8007 & 35.580 & 28.580 & 30.855 & 30.555 & 28.458 & 34.280 & 31.385 \\
3 & BJ 248 & 33.670 & 29.198 & 33.825 & 29.718 & 26.180 & 30.668 & 30.543 \\
4 & HES 04 & 32.592 & 28.822 & 24.185 & 29.983 & 26.143 & 28.352 & 28.346 \\
5 & Madhura & 30.838 & 30.383 & 32.107 & 32.560 & 28.278 & 28.777 & 30.491 \\
6 & WRAY & 37.300 & 30.383 & 32.462 & 29.437 & 36.412 & 31.383 & 32.896 \\
7 & NSS 04 & 33.132 & 26.700 & 29.273 & 22.882 & 27.715 & 32.137 & 28.640 \\
8 & CSV 19SS & 31.678 & 26.612 & 30.737 & 31.820 & 32.777 & 32.372 & 30.999 \\
9 & SSV 84 & 30.073 & 27.173 & 33.480 & 31.407 & 26.490 & 30.415 & 29.840 \\
10 & IS 20962 & 29.947 & 24.127 & 23.892 & 26.543 & 26.272 & 30.265 & 26.841 \\
11 & Keller & 32.938 & 28.865 & 30.782 & 30.555 & 32.273 & 29.655 & 30.845 \\
12 & CSH 22 SS & 34.695 & 30.457 & 33.147 & 31.753 & 27.412 & 32.580 & 31.674 \\
& Mean & 33.11 & 28.00 & 30.67 & 29.56 & 28.75 & 30.53 & \\
\hline
\end{tabular}

The effect of planting date on percent juice extractability in quarterly plantings was presented in Table $\mathbf{5}$. Percent extractability is the key factor for the overall juice yield of any genotype. The percent juice extractability was observed to be highest in June planting followed by February, December and October planting dates. NSS 208 showed highest extractability (41.5\%) in December planting followed by CSV 19SS (39.4\%) in February planting. NSS 208 and Madhura performed superior at all four times of planting for extractability.

Table 5. Effect of planting time on percent juice extractability in quarterly planting.

\begin{tabular}{|c|c|c|c|c|c|c|}
\hline \multirow{2}{*}{ S. No. } & \multirow{2}{*}{ Genotype } & \multicolumn{5}{|c|}{ Time of Planting } \\
\hline & & June & October & December & February & Mean \\
\hline 1 & NSS 04 & 33.4 & 28.3 & 26.6 & 28.5 & 29.2 \\
\hline 2 & CSH 22SS & 23.2 & 21.1 & 20.3 & 23.9 & 22.1 \\
\hline 3 & NSS 208 & 32.4 & 22.2 & 41.5 & 37.9 & 33.5 \\
\hline 4 & Wray & 35.9 & 21.8 & 28.4 & 30.6 & 29.2 \\
\hline 5 & Kellar & 33.3 & 24.7 & 32.0 & 30.6 & 30.1 \\
\hline 6 & BJ 248 & 33.4 & 25.6 & 31.1 & 23.3 & 28.4 \\
\hline 7 & CSV 19SS & 34.1 & 24.6 & 30.9 & 39.4 & 32.2 \\
\hline 8 & RSSV 47 & 35.1 & 29.4 & 29.3 & 32.9 & 31.7 \\
\hline 9 & Madhura & 34.2 & 29.5 & 33.1 & 35.0 & 32.9 \\
\hline 10 & SSV 84 & 34.1 & 21.1 & 28.5 & 36.2 & 29.9 \\
\hline \multicolumn{2}{|c|}{ C. V. (\%) } & \multicolumn{5}{|c|}{10.9} \\
\hline \multicolumn{2}{|r|}{ S. E } & \multicolumn{5}{|c|}{2.4} \\
\hline \multicolumn{2}{|c|}{ CD. (0.05) } & \multicolumn{5}{|c|}{4.8} \\
\hline
\end{tabular}

\subsection{Brix}

Percent brix varied from 12.7 (HES-04, August plantings) to 20.3 (Keller, June plantings). Of the various genotypes highest mean brix values were recorded in Keller followed by Wray and BJ-248. Of the various planting dates June plantings recorded highest percent brix. Percent brix was found to be higher during December, February and April plantings compared to August and October plantings.

The effect of planting time in quarterly plantings on brix percent was given in Table 6. Keller recorded high-

Table 6. Effect of planting date on percent brix in quarterly planting.

\begin{tabular}{|c|c|c|c|c|c|c|}
\hline \multirow{2}{*}{ S. No. } & \multirow{2}{*}{ Genotype } & \multicolumn{5}{|c|}{ Time of Planting } \\
\hline & & June & October & December & February & Mean \\
\hline 1 & NSS 04 & 17.2 & 16.6 & 15.6 & 16.5 & 16.5 \\
\hline 2 & CSH 22SS & 14.5 & 15.9 & 14.1 & 15.4 & 14.9 \\
\hline 3 & NSS 208 & 16.5 & 9.9 & 16.1 & 17.8 & 15.1 \\
\hline 4 & Wray & 18.6 & 13.4 & 17.9 & 20.8 & 17.7 \\
\hline 5 & Kellar & 18.1 & 18.8 & 19.6 & 20.1 & 19.1 \\
\hline 6 & BJ 248 & 17.5 & 18.3 & 18.2 & 18.3 & 18.1 \\
\hline 7 & CSV 19SS & 16.3 & 17.1 & 15.6 & 19.6 & 17.1 \\
\hline 8 & RSSV 47 & 16.4 & 16.7 & 17.6 & 18.7 & 17.4 \\
\hline 9 & Madhura & 15.9 & 16.5 & 15.5 & 17.7 & 16.4 \\
\hline 10 & SSV 84 & 16.2 & 11.6 & 15.4 & 16.8 & 14.9 \\
\hline \multicolumn{2}{|c|}{ C. V. (\%) } & \multicolumn{5}{|c|}{7.7} \\
\hline \multicolumn{2}{|r|}{ S. E } & \multicolumn{5}{|c|}{0.8} \\
\hline \multicolumn{2}{|c|}{ CD. (0.05) } & \multicolumn{5}{|c|}{1.7} \\
\hline
\end{tabular}


est percent brix followed by the genotype BJ 248. Other genotypes Wray, CSV 19 SS and RSSV 47 also recorded good brix percent over check variety SSV 84 . Highest juice brix percent was observed in February planting followed by June planting.

\subsection{Total Soluble Sugars}

The influence of date of plantings on percent total soluble sugars in bimonthly plantings is presented in Table 7 . Of the various planting dates December plantings have recorded highest percent total soluble sugars in various genotypes except for Wray, Keller and BJ-248 (October planting), HES-04 (February plantings) and CSH 22 SS (June plantings). Highest percent total soluble sugars were observed in Keller (19.028) followed by Wray (18.15) and BJ-248 (17.93) in October plantings.

The effect of planting date on the percent total sugars in quarterly plantings was presented in Table 8. In February planting the total sugars percent was highest followed by June planting. Keller recorded highest mean total sugar percent (17.68\%) followed by Wray and BJ $248(16.47 \%)$ respectively. The other genotypes that showed superior performance over the Check variety SSV 84 (15.07\%) were CSV 19 SS (15.88\%), RSSV 47 (15.87\%), Madhura (15.49\%) and NSS 04 (15.48\%) respectively.

\subsection{Reducing Sugars}

The influence of date of planting on percent reducing sugars in bimonthly plantings is presented in Table $\mathbf{9}$. Percent reducing sugars varied from 0.873 (Madhura, February plantings) to 2.165 (SSV-84, June plantings). Of the various genotypes lowest mean percent reducing sugars was recorded in Keller (1.134) followed by Madhura. In most of the genotypes February plantings recorded lowest percent reducing sugars.

\section{Discussion}

Of all the genotypes Wray, Keller, CSH 22SS and CSV 19SS were found to be superior with high biomass, high juice extractability, high brix and moderate grain yield plant $^{-1}$. Of the six sowings June, October, December and February sowings showed better performance compared to other sowings. The infestation by various key pests was found to be low in June planting and higher susceptibility to pests was recorded with delay in planting. December plantings cannot be recommended due to heavy frost at the time of sowing. Poor performance was recorded during August and April plantings due to shoot fly infestation and high temperatures respectively.

Performance of sweet sorghum varies under different environmental conditions. This study was conducted to determine the optimum time of sowing, throughout the year at various locations to increase number of days of factory operation. The various attributes of sweet sorghum as a bio energy crop is cane yield, juice yield and total sugars. There is a significant influence of planting time on green cane yield. Highest green cane yield was reported in Keller during December plantings. Devani \& Blanco [17] reported a similar higher stalk yields in $29^{\text {th }}$ November sowings in field trials at Monte Redno Tucuman in C. V. Roma. Hipp et al. [18] related these differences in Stem yield from different planting dates to difference in solar radiation received by plants. According to them cane yield was linearly related to radiation received during fruiting. There was a significant

Table 7. Effect of planting time on percent total soluble sugars in bimonthly planting.

\begin{tabular}{|c|c|c|c|c|c|c|c|c|}
\hline \multirow{2}{*}{ S. No. } & \multirow{2}{*}{ Genotype } & \multicolumn{7}{|c|}{ Time of Planting } \\
\hline & & June & August & October & December & February & April & Mean \\
\hline 1 & AKSSV 16 & 14.600 & 11.828 & 12.847 & 15.035 & 12.950 & 12.640 & 13.32 \\
\hline 2 & IS 8007 & 16.420 & 11.188 & 16.427 & 18.268 & 14.813 & 15.175 & 15.38 \\
\hline 3 & BJ 248 & 15.555 & 12.098 & 17.933 & 15.440 & 16.000 & 15.332 & 15.39 \\
\hline 4 & HES 04 & 12.737 & 11.820 & 12.887 & 14.730 & 15.715 & 13.438 & 13.56 \\
\hline 5 & Madhura & 14.245 & 11.355 & 12.300 & 15.000 & 14.435 & 14.040 & 13.56 \\
\hline 6 & Wray & 17.072 & 13.835 & 18.152 & 18.003 & 15.882 & 17.115 & 16.68 \\
\hline 7 & NSS 04 & 14.395 & 10.998 & 13.037 & 17.698 & 15.173 & 14.595 & 14.32 \\
\hline 8 & CSV 19 SS & 16.448 & 12.075 & 12.725 & 16.595 & 15.522 & 15.120 & 14.75 \\
\hline 9 & SSV 84 & 13.923 & 12.392 & 12.270 & 16.728 & 16.310 & 15.105 & 14.46 \\
\hline 11 & Keller & 16.955 & 14.310 & 19.028 & 17.282 & 17.845 & 18.105 & 17.25 \\
\hline 12 & CSH 22SS & 17.105 & 11.600 & 11.450 & 13.527 & 13.205 & 13.275 & 13.36 \\
\hline C. V. & & 18.07 & & & & & & \\
\hline
\end{tabular}


Table 8. Effect of planting date on percent total soluble sugars in quarterly planting.

\begin{tabular}{|c|c|c|c|c|c|c|}
\hline \multirow{2}{*}{ S. No. } & \multirow{2}{*}{ Genotype } & \multicolumn{5}{|c|}{ Time of Planting } \\
\hline & & June & October & December & February & Mean \\
\hline 1 & NSS 04 & 16.34 & 15.10 & 15.22 & 15.28 & 15.48 \\
\hline 2 & CSH 22SS & 13.17 & 13.29 & 14.31 & 13.43 & 13.55 \\
\hline 3 & NSS 208 & 15.17 & 9.18 & 15.83 & 14.88 & 13.77 \\
\hline 4 & Wray & 17.95 & 12.47 & 17.23 & 18.28 & 16.48 \\
\hline 5 & Kellar & 17.74 & 16.92 & 18.10 & 17.96 & 17.68 \\
\hline 6 & BJ 248 & 16.46 & 15.96 & 15.29 & 16.16 & 16.47 \\
\hline 7 & CSV 19SS & 14.70 & 15.30 & 16.02 & 17.52 & 15.88 \\
\hline 8 & RSSV 47 & 14.86 & 15.03 & 16.86 & 16.74 & 15.87 \\
\hline 9 & Madhura & 15.46 & 15.17 & 16.00 & 15.35 & 15.49 \\
\hline 10 & SSV 84 & 15.41 & 10.36 & 15.47 & 15.04 & 15.07 \\
\hline \multicolumn{2}{|c|}{ C. V. (\%) } & \multicolumn{5}{|c|}{9.89} \\
\hline \multicolumn{2}{|r|}{ S. E } & \multicolumn{5}{|c|}{1.13} \\
\hline \multicolumn{2}{|c|}{ CD. (0.05) } & \multicolumn{5}{|c|}{2.35} \\
\hline
\end{tabular}

influence of interaction of genotype and date of planting on percent juice extractability.

Significant genotype $\times$ date of planting interaction was absent for brix, percent total soluble sugars and percent reducing sugars. Absence of this interaction shows that they are varietal characters and are less influenced by environment. However there is a significant influence of date of planting on brix and percent total soluble sugars. The percent brix was found to be highest in June plantings followed by October, December and February plantings. On the contrary, Broadhead [19] reported that brix was not affected by planting date. In contrast to the above results Almodares et al. [10] recorded a higher brix in cultivars planted on May 1 than June 1 in Iran. This difference in performance may be due to difference in climatic conditions. Most of the cultivars recorded highest percent total soluble sugars during October plantings. Naoyuki et al. [20] reported that the stem and total sugar yield during dry season was about $60 \%$ and $75 \%$ respectively with that of rainy season.

Most of the genotypes had lowest percent of reducing sugars during February planting compared to the June planting. This indicated that the invertase activity and inversion of sugars had certainly had the influence of temperature in addition to the genotypic variation that already exists. Ya Li Zhao et al. [21] reported that total Calculated Ethanol Yield (CEY) from the carbohydrates increased with time after anthesis and with crop cycle length, ranging between 4867 and 13,032 L/ha on 40 DAA during the two years. It is also mentioned that the effects of each factor of year, harvest time, and genotype on biomass, carbohydrates yield, and CEY are highly significant. The interaction of genotype with year (environment) had significant effects on the total CEY. They recommended beginning the harvest of sweet sorghum upon the early maturity of the cultivars from around 20 DAA and this will result in a harvest period of around two months until grain maturity of the late cultivars for ethanol production in North China. In a similar study by Almodares et al. [22], the relationships have linear and positive responses which indicate that as the plant grows, there are more leaves, more photosynthesis (NAR), and more growth (RGR and CGR) which increase sucrose

Table 9. Effect of planting time on percent reducing sugars in bimonthly planting.

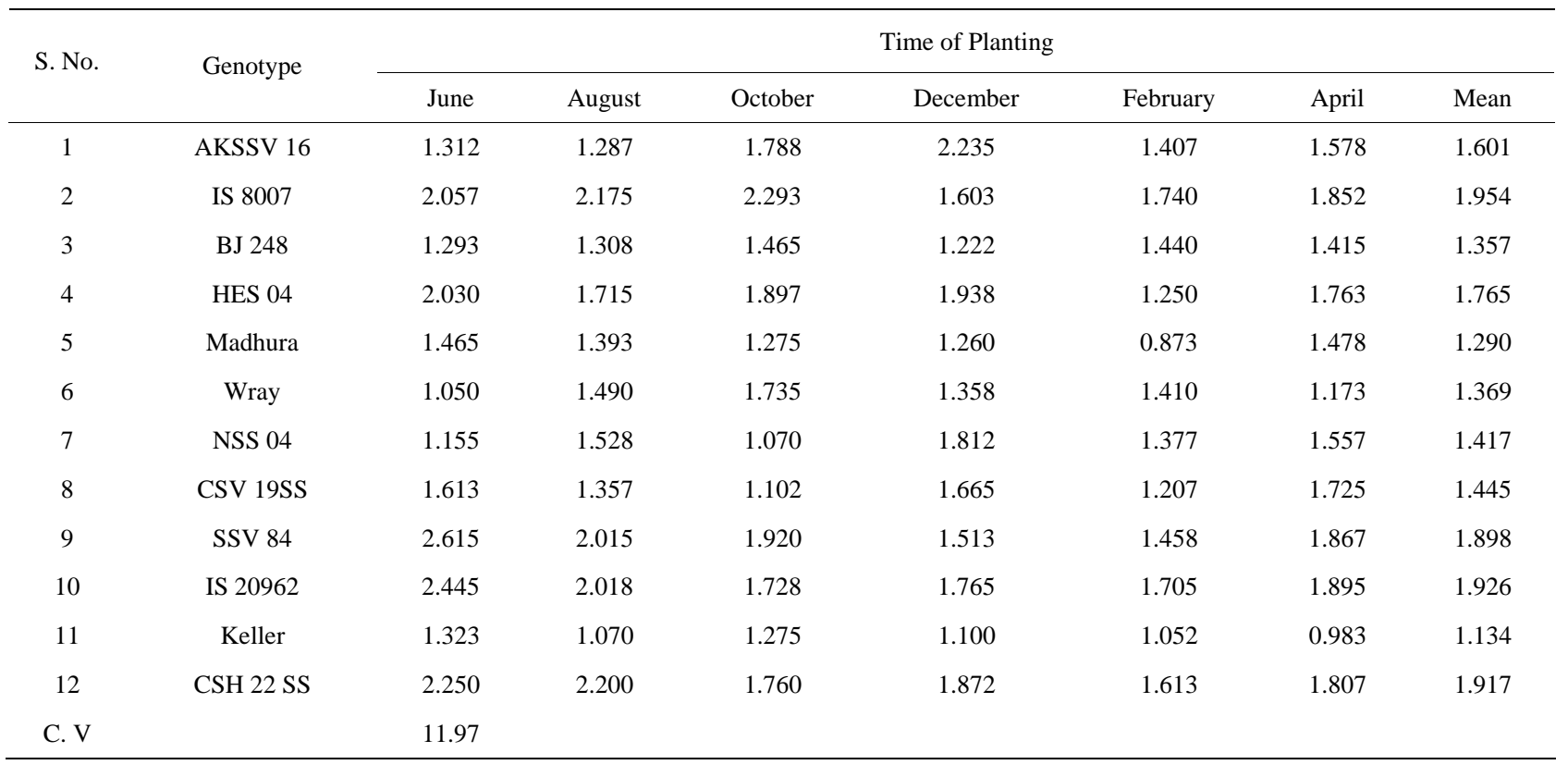


content in the stem. The results showed as sweet sorghum cultivars and lines grow, LAI, NAR and RGR will be increased. As a result, the amount of sucrose increased while the amount of invert sugar (glucose, fructose, maltose and xylose) decreased. The results indicate that the time of harvesting sweet sorghum, cultivars and lines is dependent on the purpose of planting. They also reported that if the purpose of planting is to produce crystal sugar, it is suggested to harvest sweet sorghum cultivars and lines at hard dough-post maturity stage when plants had the highest sucrose and lowest invert sugars, since invert sugars influence crystallization. Harvesting sweet sorghum cultivars and lines at other growth stages are more suitable for liquid sugar production.

Thus we conclude that under the Indian conditions the factory requirements can be met through out the year as four sowings are found to be optimum i.e., June, October, December and February. However December plantings are suitable in sugarcane growing areas where night temperatures are above $20^{\circ} \mathrm{C}$. Of all the genotypes Wray, Keller, CSV 19SS and NSS-04 showed better performance compared to others.

\section{Acknowledgements}

The authors acknowledge the financial support of National Agricultural Technology Project, RNPS-24 (20002005) and National Fund for Basic, Strategic and Frontier Application Research in Agriculture (NFBSFARA) (20112015) on sweet sorghum through Indian Council of Agricultural Research, New Delhi.

\section{REFERENCES}

[1] S. Wayne and R. Frederiksen, "Sorghum Origin, History, Technology and Production," John Wiley Publishers, New York, 2005.

[2] F. A. Showemimo, J. N. Buah, A. A. Addo-Quaye and E. Asare-Bediako, "Nature of Inheritance and Genetic Components of Some Agronomic Traits in Sorghum," International Journal of Agricultural Research, Vol. 1, No. 5, 2006, pp. 503-508. doi:10.3923/ijar.2006.503.508

[3] E. Gnansounoua, A. Dauriata and C. E. Wyman, "Refining Sweet Sorghum to Ethanol and Sugar: Economic Trade-Offs in the Context of North China," Bioresource Technology, Vol. 96, No. 9, 2005, pp. 985-1002. doi:10.1016/j.biortech.2004.09.015

[4] I. Dolciotti, S. Mambelli, S. Grandi and G. Venturi, “Comparison of Two Sorghum Genotypes for Sugar and Fiber Production" Industrial Crops and Products, Vol. 7, No. 2-3, 1998, pp. 265-272.doi:1016/S0926-6690(97)00057-5

[5] International Energy Agency, "World Energy Outlook," OECD Publishing, Paris, 2008.

[6] IPCC (Intergovernmental Panel on Climate Change), “Climate Change Synthesis Report,” 2007.

http://www.ipccch/ipccreoprts/ar4-srren.html
[7] I. C. Anderson, D. B. Buxton, A. Hallam and E. Hunter, "Biomass Production and Ethanol Potential from Sweet Sorghum”, 1995.

http://www.leopold.iastate.edu/research/grants/1995/1991-46_

[8] A. Soltani, A. Almodares, "Evaluation of the Investments in Sugar Beet and Sweet Sorghum Production,” National Convention of Sugar Production from Agricultural Products, Ahwaz, 13-16 March 1994.

[9] U. D. Chavan, J. V. Patil and M. S. Shinde, “An Assessment of Sweet Sorghum Cultivars for Ethanol Production,” Sugar Technology, Vol. 11, No. 4, 2009, pp. 219-223.

[10] A. Almodares, A. Sepahi and A. D. Karve, "Effect of Planting Date on Yield and Sugar Production of Sweet Sorghum,” Annals of Plant Physiology, Vol. 8, 1994, pp. 49-54.

[11] S. Y. Besheit, M. K. Ali, M. G. Beshay and A. A. Dooh, "Stalk and Technological Characteristics of Two Sweet Sorghum Cultivars as Influenced by Sowing Date,” Advances Agriculture Research, Vol. 1, No. 1, 1996, pp. 28-35.

[12] M. T. Taha Nour-El-Hoda and M. M. El-Koliey, "Response of Sweet Sorghum to Irrigation Intervals and Nitrogen Fertilization,” Journal of Agricultural Scienc, Vol. 30, 1999, pp. 65-80.

[13] C. V. Ratnavathi, B. Dayakar Rao, P. G. Padmaja, S. Ravi Kumar, C. Sashidhara Reddy, B. S. Vijaya Kumar, M. Pallavi, V. V. Komala, D. Gopala Krishna and N. Seetharama, "Sweet Sorghum-The Wonder Crop for Biofuel Production,” National Research Centre for Sorghum, Hyderabad, 2005.

[14] M, Dubois, K. A. Gilles, J. K. Hamilton, P. A. Rebers and F. Smith, "Colorimetric Method for Determination of Sugar and Related Substances,” Analytical Chemistry, Vol. 28, No. 3, 1956, pp. 350-356. doi:10.1021/ac60111a017

[15] G. L. Miller, "Use of Dinitro Salicylic Acid Reagent for Determination of Reducing Sugars," Analytical Chemistry, Vol. 31, No. 3, 1959, pp. 426-428. doi:10.1021/ac60147a030

[16] G. W. Snedecor and W. G. Cochran, "Statistical Methods," Oxford and IBH Publishing Company, New Delhi, 1968.

[17] M. R. Devani and A. S. Blanco, "Optimum Sowing Date for Sweet Sorghum,” Revista Industrial y Agricola de Tucuman, Vol. 66, 1989, pp. 113-118.

[18] W. H. Billy, W. R. Cowely, C. J. Gerard and B. A. Smith, "Influence of Solar Radiation and Date of Planting on Yield of Sweet Sorghum,” Crop science, Vol. 10, No. 1, 1970, pp. 91-92. doi:10.2135/cropsci1970.0011183X001000010033x

[19] D. M. Broadhead, "Effect of Planting Date and Maturity on Juice Quality of Rio Sweet Sorghum,” Agronomy Journal, Vol. 64, 1970, p. 3.

[20] N. Tsuchihashi and Y. Goto, "Cultivation of Sweet Sorghum (Sorghum Bicolour (L.) Moench), Determination of Its Harvest Time to Make Use as the Raw Material for Fermentation, Practiced during Rainy Season in Dry Land of Indonesia,” Plant Production Science, Vol. 7, No. 4, 2004, pp. 442-448. doi:10.1626/pps.7.442 
[21] Y. L. Zhao, A. Dolat, Y. Steinberger, X. Wang, A. Osman and G. H. Xie, "Biomass Yield and Changes in Chemical Composition of Sweet Sorghum Cultivars Grown for Biofuel," Field Crops Research, Vol. 111, No. 1-2, 2009, pp. 55-64. doi:10.1016/j.fcr.2008.10.006
[22] A. Almodares, A. Sepahi and M. Shirvani, "Sweet Sorghum Cultural Practices in Iran," Proceedings of the 1st International Sweet Sorghum Conference, Chinese Academy of Sciences, Beijing, 14-19 September 1997, pp. 175-183. 